\title{
Advanced Stage Hepatocellular Carcinoma with Multiple Metastasis and Vascular Thrombosis: A Case of Complete Response to Sorafenib
}

\section{Carcinoma Hepatocelular em Estádio Avançado com Metastização Múltipla e Trombose Vascular: Um Caso de Resposta Completa ao Sorafenib}

\author{
Adélia SIMÃO $\square^{1,2}$, Raquel SILVA ${ }^{1,2}$, Lurdes CORREIA ${ }^{1,2}$, Filipe Caseiro ALVES ${ }^{3,4}$, Armando CARVALHO ${ }^{1,2}$, \\ J.M. Nascimento COSTA ${ }^{1,2}$ \\ Acta Med Port 2016 Feb;29(2):139-142 - http://dx.doi.org/10.20344/amp.6799
}

\section{ABSTRACT}

Sorafenib is a multi-targeted tyrosine kinase inhibitor, with antiangiogenic and antiproliferative properties, approved for the treatment of advanced hepatocellular carcinoma. It induces a significant increase in the median overall survival, despite a complete response to treatment being rare. We report a clinical case of a 60 -year-old male with hepatic cirrhosis, Child-Pugh class A and performance status 0 , and advanced hepatocellular carcinoma. The primary tumor measured $17 \times 8 \mathrm{~cm}$ and had diffuse intrahepatic metastization, extensive lung and left adrenal invasion, as well as thrombosis of inferior vena cava, with projection to the right atrium. This patient showed a rapid and complete response to sorafenib, evaluated by mRECIST (modified Response Evaluation Criteria in Solid Tumors), that remains after three years of treatment.

Keywords: Carcinoma, Hepatocellular/drug therapy; Neoplasm Metastasis; Remission Induction; Sorafenib.

\section{RESUMO}

O sorafenib, um inibidor de múltiplas cinases com propriedades antiangiogénicas e antiproliferativas foi aprovado para o tratamento de carcinoma hepatocelular em estádio avançado por induzir um prolongamento da sobrevivência global estatisticamente significativo, sendo a resposta completa rara. Relata-se o caso clínico de um homem de 60 anos com cirrose hepática classe A de Child-Pugh e performance status 0 e carcinoma hepatocelular em estádio avançado (com tumor primitivo medindo $17 \times 8 \mathrm{~cm}$, metastização intrahepática difusa, pulmonar maciça e da suprarrenal esquerda e ainda trombose da veia cava inferior com extensão e projeção na câmara da aurícula direita), que apresentou resposta completa com sorafenib, avaliada pelos critérios mRECIST (modified Response Evaluation Criteria in Solid Tumors). Esta resposta mantem-se após três anos de tratamento.

Palavras-chave: Carcinoma Hepatocelular/quimioterapia; Indução de Remissão; Metástase Neoplásica; Sorafenib.

\section{BACKGROUND}

Sorafenib is an oral multiple tyrosine kinase inhibitor that exerts its therapeutic benefit by inhibiting Raf kinases (CRAF, BRAF and V600 BRAF), platelet-derived growth factor receptor, FIt-3, c-KIT, and the kinase activities of vascular endothelial growth factor receptor (VEGFR)-2 and VEGFR-3. ${ }^{1}$

The efficacy and safety of sorafenib for advanced HCC were assessed in the SHARP (Randomized Sorafenib HCC Assessment Protocol) study ${ }^{2}$ and also in the Asia-Pacific (AP) study. ${ }^{3}$ In those, multi-center, phase III double-blind, placebo-controlled studies, patients with $\mathrm{HCC}$ and cirrhosis, mainly in Child-Pugh stage A, were included. In the sorafenib group (400 mg twice daily), a statistically significant increase of the overall survival and time to symptomatic progression were documented. However, the rate of partial response to treatment, assessed by Response Evaluation Criteria in Solid Tumors (RECIST), was $2 \%$ in the SHARP study, ${ }^{2}$ and no complete response was documented. These results were confirmed in the AP study, ${ }^{3}$ with $3 \%$ of partial responses. Consequently, sorafenib received the European Medicines Agency (EMA) authorization in October 2007 and was approved by the USA United Food and Drug Administration (FDA) in November 2007.

Sorafenib emerged as the first effective systemic treatment in HCC after 30 years of research, and is currently the standard-of-care for patients with advanced tumors. ${ }^{2}$ It is indicated for patients with well-preserved liver function (Child-Pugh A class) and with advanced tumors BCLC C - or those tumors progressing under loco-regional therapies. ${ }^{4}$ To date, sorafenib has been applied to a large number of patients worldwide and became an important therapeutic option for HCC.

Specific populations in which efficacy can be expected have not yet been elucidated, and possible biomarkers for predicting prognosis remain unclear. Recent studies have reported that an early response of tumor markers, such as $\alpha$-fetoprotein and des-y-carboxyprothrombin, may predict the treatment efficacy of sorafenib in advanced

1. Serviço de Medicina Interna A. Centro Hospitalar e Universitário de Coimbra. Coimbra. Portugal.

2. Departamento de Medicina. Faculdade de Medicina. Universidade de Coimbra. Coimbra. Portugal.

3. Departamento de Radiologia. Centro Hospitalar e Universitário de Coimbra. Coimbra. Portugal.

4. Departamento de Radiologia. Faculdade de Medicina. Universidade de Coimbra. Coimbra. Portugal.

$\triangle$ Autor correspondente: Adélia Simão. adeliasimao@gmail.com

Recebido: 14 julho de 2015 - Aceite: 25 de outubro de 2015 | Copyright $\odot$ Ordem dos Médicos 2016 
HCC patients. 5,6 Other studies have reported that serum or plasma components of proliferative and angiogenic signals, or molecules related to angiogenesis pathways may be sensitive indicators of the response to treatment with sorafenib and of drug-related adverse events. ${ }^{7}$

Although sorafenib rarely induces a complete response $(\mathrm{CR})$, some patients have shown remarkable tumor shrinkage and/or absolute tumor necrosis. However, which patients are likely to exhibit a remarkable response and how sorafenib affects such patients remain unknown.

We report the case of a patient with advanced stage hepatocellular carcinoma with multiple metastasis, who presented a rapid and $\mathrm{CR}$ to sorafenib.

\section{Case presentation}

A 60-year-old black man, born in Guinea, resident in Portugal since age 18, with liver cirrhosis (Child-Pugh A), chronic alcoholism, chronic HBV infection (currently HBV DNA negative) and positive anti-HCV (with undetectable RNA HCV) presented with abdominal pain, located in the right upper quadrant, in May 2012. The pain had begun two months earlier and worsened recently. He also reported weight loss (more than $10 \%$ of body weight within the last year). On examination he was well nourished (weight: 82 $\mathrm{kg}$, height: $183 \mathrm{~cm}$, BMl: $24.5 \mathrm{~kg} / \mathrm{m}^{2}$ ), normotensive, with facial scars from burns and lagophthalmos. The abdomen was distended, with slightly painful hepatomegaly, without ascites. He had no edema of the lower limbs.

$C T$ revealed a hypervascular mass occupying almost all of the right liver lobe (segments VIII and V), with $17 \mathrm{~cm} \times 8.0$ $\mathrm{cm}$, with washout in late phase, porto-systemic shunts and multiple dilated vessels inside, and also diffuse intrahepatic metastasis (Fig. 1); massive pulmonary metastasis with countless nodules in all lobes (Fig. 2); metastasis in the
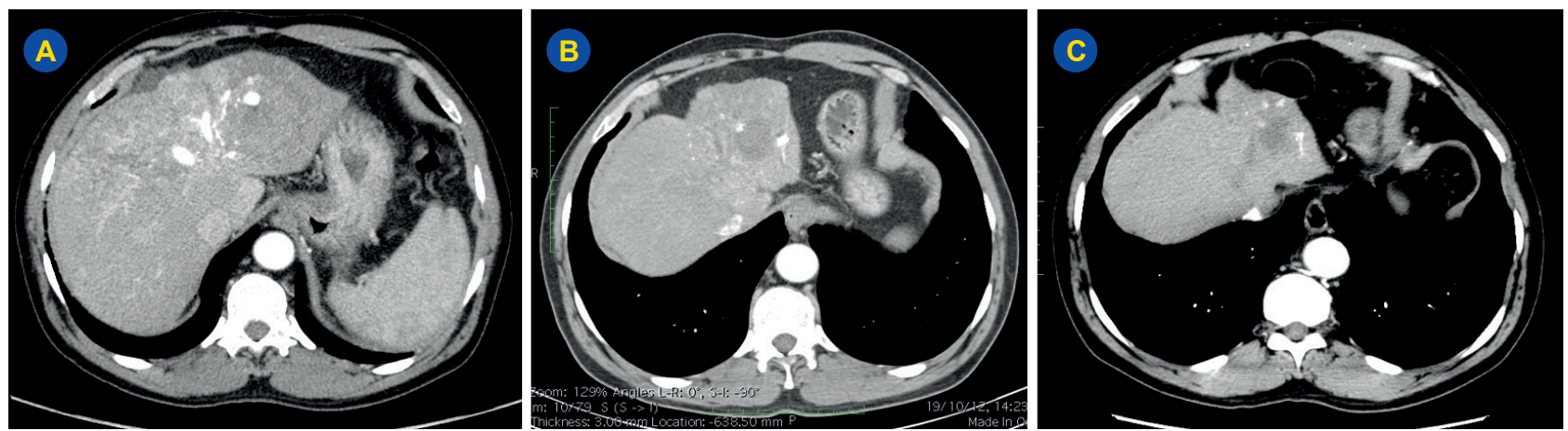

Figure 1 - Abdominal CT (arterial phase): follow-up with sorafenib therapy (primary liver tumor). A) Before therapy; B) After 3 months of sorafenib; C) After 6 months of sorafenib.
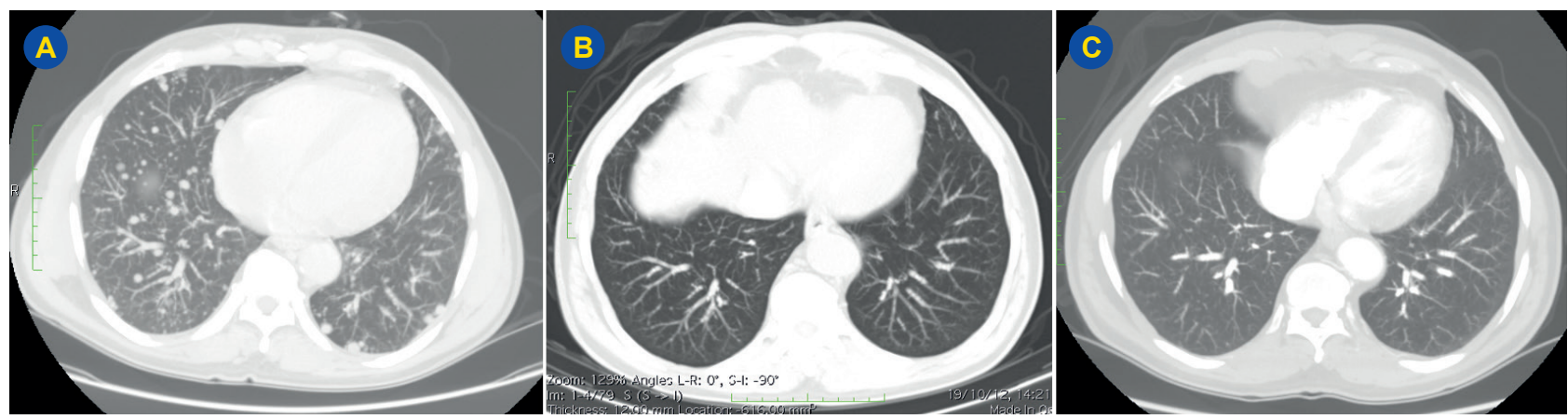

Figure 2 - Chest CT: follow-up with sorafenib therapy (lung metastases). A) Before therapy; B) After 3 months of sorafenib; C) After 6 months of sorafenib.
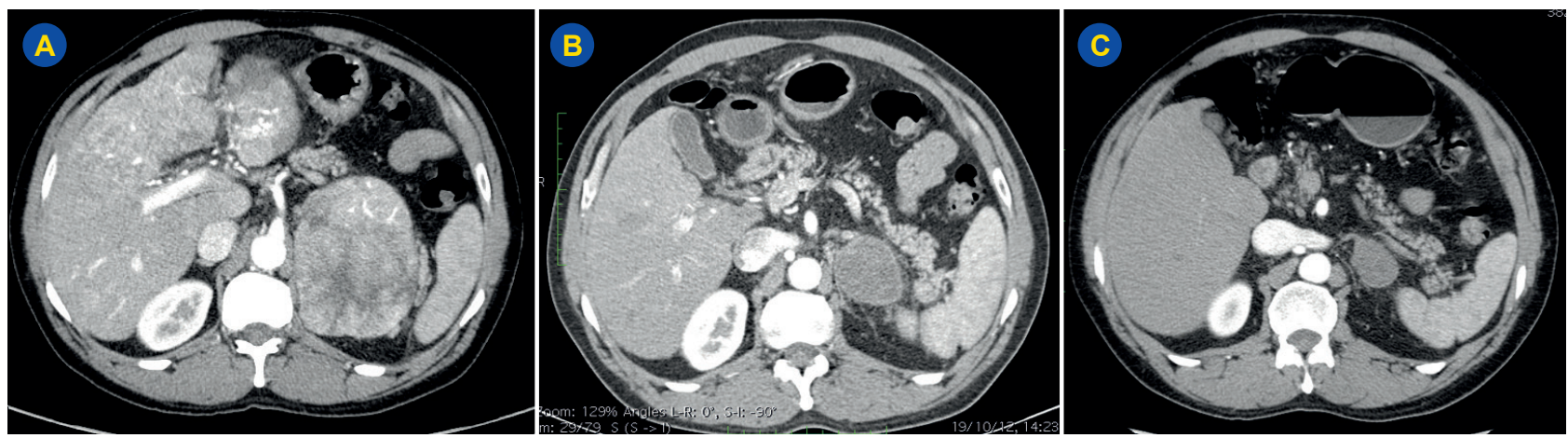

Figure 3 - Abdominal CT: follow-up with sorafenib therapy (adrenal metastasis). A) Before therapy; B) After 3 months of sorafenib; C) After 6 months of sorafenib. 


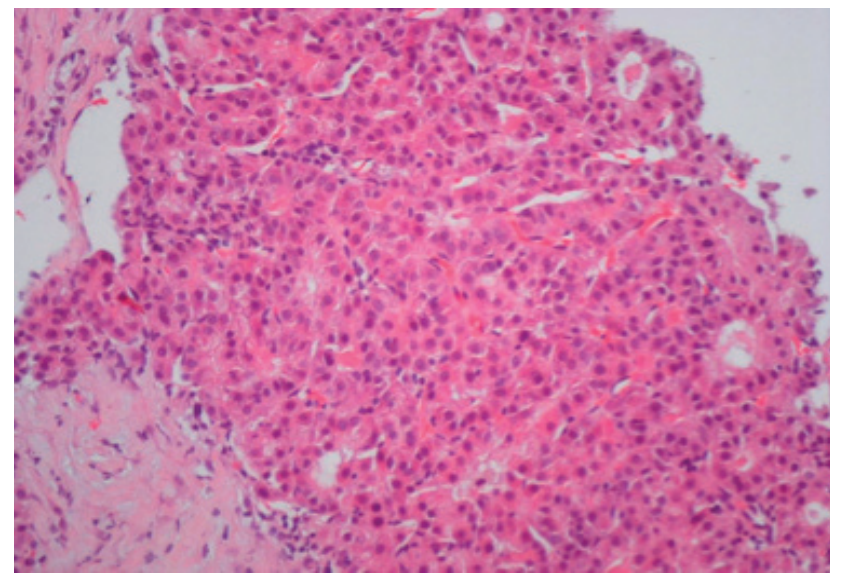

Figure 4 - Liver biopsy showing a moderately differentiated HCC (G2) in cirrhotic liver (HE 200X)

left adrenal gland, with $12 \mathrm{~cm} \times 8.0 \mathrm{~cm}$ (Fig. 3); inferior vena cava thrombosis with extension to the right atrium, and thrombus in the left branch of the portal vein. Initial AFP level was $479 \mathrm{ng} / \mathrm{mL}$, and liver biopsy confirmed a moderately differentiated HCC (G2) in a cirrhotic liver (Fig. 4). The patient was in advanced stage (C) of the BCLC classification and in very good clinical condition, and started sorafenib (400 mg twice daily).

The control CT after 3 months of therapy showed complete resolution of the pulmonary metastatic lesions (Fig. 2B), a significant reduction in the size $(5.7 \mathrm{~cm} \times 6.0$ $\mathrm{cm}$ ) and perfusion (without arterial enhancement) of the primary liver tumor (Fig. 1B); reduction of the number and size of intrahepatic satellite lesions (hypodense in both phases) and significant reduction of the left adrenal lesion $(3.6 \mathrm{~cm} \times 2.5 \mathrm{~cm})$ (Fig. 3B) that captured the venous phase contrast. The inferior vena cava thrombosis presented marked size reduction of tumor infiltration and of its extent, without reaching the right atrium. A de novo thrombus without enhancement throughout the left hepatic vein was seen.

At six months, AFP normalized $(3.7 \mathrm{ng} / \mathrm{mL})$, a favorable response to treatment remained (Fig.s $1 \mathrm{C}, 2 \mathrm{C}$ and $3 \mathrm{C}$ ), and the medication had been well tolerated.

After one year of treatment, the patient presented with atrophy of the left liver lobe, a hypodense nodule in segment III $(2.4 \mathrm{~cm})$, hypodense secondary nodules, stable in number and dimensions (the largest in the segment $\mathrm{V}$, $1.1 \mathrm{~cm}$ ), and the left adrenal nodule with $3.0 \mathrm{~cm} \times 2.1 \mathrm{~cm}$. Thrombosis in the left hepatic vein persisted, extending to the inferior vena cava, with reduction in its caliber, and decreased thrombus in the left branch of the portal vein.

After three years, the patient remained clinically stable under sorafenib medication, referring skin dryness and normal blood pressure with enalapril $10 \mathrm{mg} 1 \mathrm{id}$. Analytically, AFP remained normal and only increased GGT (about 6xULN) was observed. Control CT maintained mRECIST $\mathrm{CR}$ and Chest $X$ ray was normal (Fig. 5B).

\section{DISCUSSION}

This clinical case illustrates a rapid and CR to sorafenib therapy, according to the mRECIST, criteria developed to assess the response in patients with HCC, based on measurement of viable tumor with arterial enhancement on a dynamic imaging technique,, 89 and also on tumor marker response.

In our patient it was clearly demonstrated that dramatic therapeutic responses are possible with sorafenib in metastatic HCC. Although CR under sorafenib is obviously uncommon, it has probably been underestimated in initial studies by the use of conventional RECIST criteria.

Indeed, Poullenot $\mathrm{F}$ et $\mathrm{al}^{10}$ related four cases of CR among 250 patients treated with sorafenib over five years, therefore accounting for $1.5 \%$ of the total. Shiba $S$ et al ${ }^{11}$ conducted a nationwide survey in Japan to examine the situation of patients with HCC treated with sorafenib who obtained a CR according to the mRECIST criteria; among
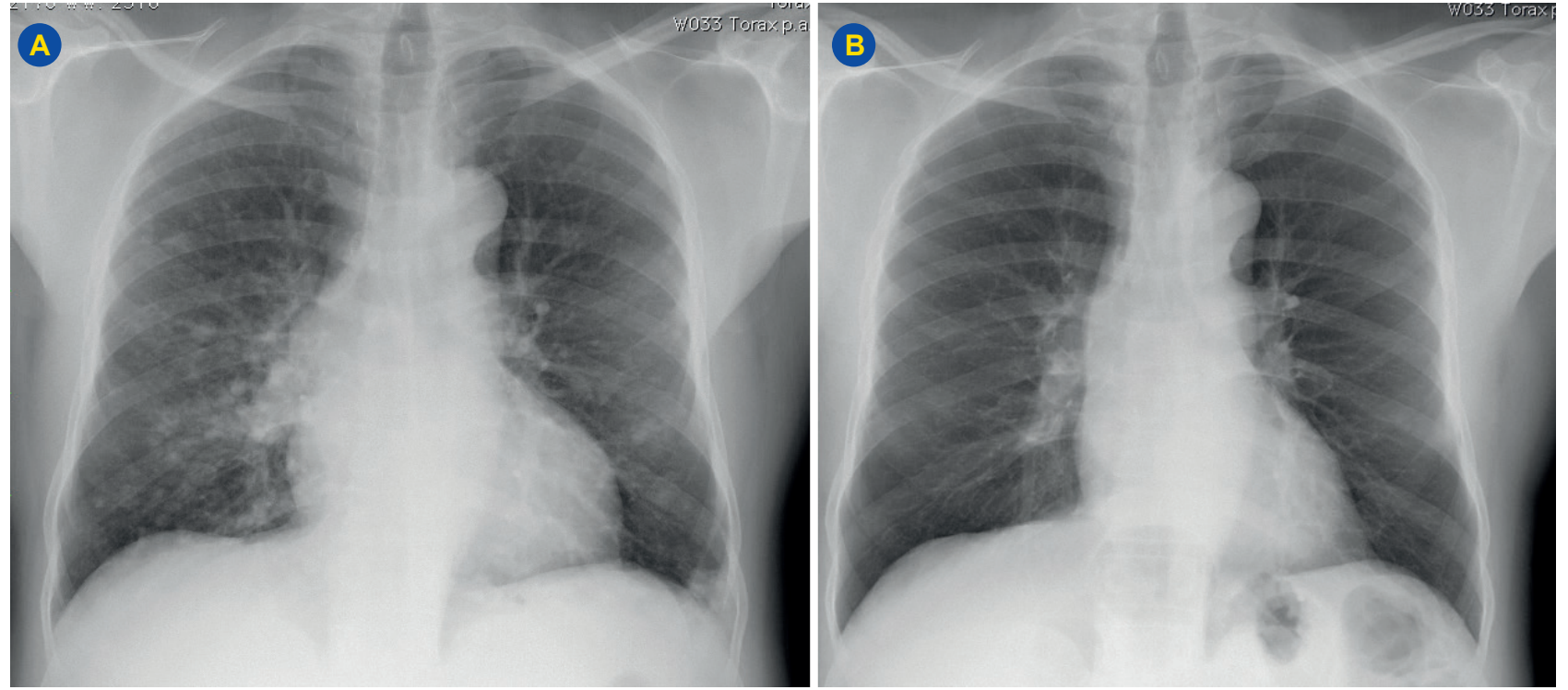

Figure 5 - Chest $\mathrm{X}$ ray. A) Before treatment and B) After 3 years of sorafenib. 
to the Liver Cancer Study Group of Japan, 18 patients $(0.6 \%)$ obtained a CR. In this study female gender, low body weight ( $<59 \mathrm{~kg})$, early clinical stage, and a small initial dose of sorafenib $(p<0.05)$ were identified as predictive factors for a CR. Furthermore, specific adverse events (palmarplantar erythrodysesthesia syndrome, hypertension, diarrhea, alopecia, fatigue, nausea and anorexia) were frequently observed in the $\mathrm{CR}$ group $(p<0.05)$. Our patient profile is quite different from that reported in this study. He is a man, weighing $80 \mathrm{~kg}$, with a large tumor burden, and has taken the standard dose of medication all the time. As side effects he just had dry skin and hypertension.

The explanation for the rarity of a CR in HCC patients under sorafenib therapy is unknown. In our case, it is remarkable the presence of porto-systemic shunts and multiple dilated vessels inside de tumor. So, we hypothesize that the exceptional response in this case may be due mainly to the antiangiogenic effect of sorafenib. Moreover, reduced portal blood flow caused by the tumor thrombus could have resulted in a persistent hypoxic tissue environment, also leading to progressive tumor regression after sorafenib therapy. Partial recanalization of the inferior vena cava thrombosis and of portal vein could have resulted from complete remission of tumor cells, similarly to what happened in another published case. ${ }^{12}$

There is no clear recommendation regarding the question of sorafenib discontinuation in this unusual situation, but the most common prevailing attitude is to indefinitely maintain

\section{REFERENCES}

1. Wilhelm SM, Carter C, Tang L, Wilkie D, McNabola A, Rong H, et al. BAY 43-9006 exhibits broad spectrum oral antitumor activity and targets the RAF/MEK/ERK pathway and receptor tyrosine kinases involved in tumor progression and angiogenesis. Cancer Res. 2004;64:7099-109.

2. Llovet JM, Ricci S, Mazzaferro V, Hilgard P, Gane E, Blanc JF, et al. Sorafenib in advanced hepatocellular carcinoma. $\mathrm{N}$ Engl $\mathrm{J}$ Med. 2008;359:378-90.

3. Cheng AL, Kang YK, Chen Z, Tsao CJ, Qin S, Kim JS, et al. Efficacy and safety of sorafenib in patients in the Asia-Pacific region with advanced hepatocellular carcinoma: a phase III randomised, double-blind, placebo-controlled trial. Lancet Oncol. 2009;10:25-34.

4. EASL-EORTC Clinical Practice Guidelines: Management of hepatocellular carcinoma. J Hepatol. 2012;56:908-43.

5. Shao YY, Lin ZZ, Hsu C, Shen YC, Hsu CH, Cheng AL. Early alphafetoprotein response predicts treatment efficacy of antiangiogenic systemic therapy in patients with advanced hepatocellular carcinoma. Cancer. 2010;116:4590-6.

6. Ueshima K, Kudo M, Takita M, Nagai T, Tatsumi C, Ueda T, et al. Desgammacarboxyprothrombin may be a promising biomarker to determine the therapeutic efficacy of sorafenib for hepatocellular carcinoma. Dig Dis. 2011;29:321-5. therapy to avoid a potential reactivation of the tumor. This management was applied in most of the case reports previously published. It should be stressed, however, that this attitude is not supported by strong biological or clinical evidence. Nevertheless, this issue is especially crucial because: 1) side effects of sorafenib may strongly impact the quality of life; 2 ) there are currently no data on the longterm safety of this drug; and 3 ) the cost of the treatment has to be stressed. ${ }^{10}$

In our patient we have chosen to continue the treatment because it has been very well tolerated, but it is not clear whether sorafenib maintenance is beneficial and which strategy is the best for $\mathrm{CR}$.

\section{PROTECTION OF HUMANS AND ANIMALS}

The authors declare that the procedures were followed according to the regulations established by the Clinical Research and Ethics Committee and to the Helsinki Declaration of the World Medical Association.

\section{DATA CONFIDENTIALITY}

The authors declare having followed the protocols in use at their working center regarding patient's data publication.

\section{CONFLICTS OF INTEREST}

The authors declare that there are no conflicts of interest.

\section{FUNDING SOURCES}

No subsidies or grants contributed to this work.

7. Miyahara K, Nouso K, Tomoda T, Kobayashi S, Hagihara H, Kuwaki K, et al. Predicting the treatment effect of sorafenib using serum angiogenesis markers in patients with hepatocellular carcinoma. J Gastroenterol Hepatol. 2011;26:1604-11.

8. Llovet JM, Di Bisceglie AM, Bruix J, Kramer BS, Lencioni R, Zhu AX, et al. Design and endpoints of clinical trials in hepatocellular carcinoma. $J$ Natl Cancer Inst. 2008;100:698-711.

9. Lencioni R, Lovet JM. Modified RECIST (mRECIST) assessment for hepatocellular carcinoma. Semin Liver Dis. 2010;30:52-60.

10. Poullenot F, Bioulac-Sage P, Laumonier H, Saric J, Carteret T, Blanc JF. Hepatocellular carcinoma treated by sorafenib with complete radiological response according to $\mathrm{mRECIST}$ criteria: Could we stop the treatment? About four cases. Acta Oncol. 2014;53:420-32.

11. Shiba S, Okusaka T, Ikeda M, Hidetsugu S, Ichida T. Characteristics of 18 patients with hepatocellular carcinoma who obtained a complete response after treatment with sorafenib. Hepatol Res. 2014;44:1268-76.

12. Novi M, Lauritano EC, Piscaglia AC, Barbaro B, Zocco MA, Pompili $M$, et al. Portal vein tumor thrombosis revascularization during sorafenib treatment for hepatocellular carcinoma. Am J Gastroenterol. 2009;104:1852-4. 